\title{
Population Dynamics of Mixed Cultures of Yeast and Lactic Acid Bacteria in Cider Conditions
}

\author{
Leila Roseli Dierings, Cíntia Maia Braga, Karolline Marques da Silva, Gilvan Wosiacki \\ and Alessandro Nogueira* \\ Departamento de Engenharia de Alimentos; Setor de Ciências Agrárias e de Tecnologia;Universidade Estadual de \\ Ponta Grossa; Av. General Carlos Cavalcanti 4748; Campus Universitário de Uvaranas; 84030-900 - Ponta \\ Grossa - PR - Brasil
}

\begin{abstract}
The objective of this work was to study the malolactic bioconversion in low acidity cider, according Brazilian conditions. The apple must was inoculated with Saccharomyces cerevisiae or S. cerevisiae with Oenococcus oeni. The control contained the indigenous microorganisms. Fermentation assays were carried out with clarified apple must from the Gala variety. At the beginning of fermentation, there was a fast growth of the non-Saccharomyces yeast population. Competitive inhibition occurred in all the assays, either with inoculated or indigenous populations of the yeast. The lactic acid bacteria count was ca. $1.41 \cdot 10^{2} \mathrm{CFU} / \mathrm{mL}$ at the beginning and $10^{6} \mathrm{CFU} / \mathrm{mL}$ after yeast cells autolysis. The lactic bacteria $\mathrm{O}$. oeni reached the highest population $\left(10^{7} \mathrm{CFU} / \mathrm{mL}\right)$ when added to the apple must after the decline of the yeast. The malic acid was totally consumed during the alcoholic fermentation period (80.0 to $95.5 \%)$ and lactic acid was still synthesized during the 35 days of malolactic fermentation. These results could be important in order to achieve a high quality brut, or sec cider obtained from the dessert apple must.
\end{abstract}

Key words: apiculate yeast, cider, lactic acid bacteria, alcoholic fermentation

\section{INTRODUCTION}

The chemical composition of cider is established during three fermentative stages: the oxidative (apiculate or non-Sacharomyces yeast), the alcoholic (mainly Saccharomyces sp.) and the malolactic (lactic acid bacteria, LAB). Oxidative fermentation is the first phase observed in natural fermentations, being responsible for aromatic compound formation with fruity and floral aromas (Drilleau 1996; Valles et al. 2008). The main microorganisms isolated in this phase are apiculate yeasts such as Metschnikowia pulcherrima, Pichia guilliermondii, Hanseniaspora valbyensis and $H$. uvarum, Candida parapsilosis, Lachancea cidri, Candida sake, Candida tropicalis, Kluyveromyces marxianus and Kloeckera sp. (Martinez et al. 1989; Beech 1993; Coton et al. 2006; Valles et al. 2008). Fermentation begins due to nonSaccharomyces yeast, which is usually present in the apple epicarp and processing equipment. The population may reach around $10^{6}$ colony forming units (CFU) per $\mathrm{mL}$, and they are inhibited by Saccharomyces sp. (Fleet 1990; Morrisey et al. 2004; Coton et al. 2006). This stage may last between 5 and 15 days in natural fermentations in French cider conditions (Le Quéré and Drilleau 1998).

There are some problems related to natural fermentation, such as the lack of control, which can result in a decrease in the quality and the risk of contamination. The utilization of commercial

*Author for correspondence: alessandronog@yahoo.com.br 
yeast, usually in the active dry form, allows for a better control of fermentation and reduces the risk of negative organoleptic effects resulting from the growth and metabolism of other indigenous yeasts (Cabranes et al. 1997; Valles et al. 2008). Natural yeasts of the Saccharomyces genus are observed in apple must in a population of approximately $6.0 \cdot 10^{4} \mathrm{CFU} / \mathrm{mL}$ and they may reach a maximum population of 1.0 at $4.0 \cdot 10^{7} \mathrm{CFU} / \mathrm{mL}$ when the fermentation reaches its maximum velocity. The growth stabilizes after the consumption of 10 to 15 g/L of sugar (Le Quéré and Drilleau 1998), whereas, when viable cells of $S$. cerevisiae are inoculated in apple must in a population of around $10^{6} \mathrm{CFU} / \mathrm{mL}$, they reach the stationary phase with a population of $10^{7} \mathrm{CFU} / \mathrm{mL}$ (Herrero et al. 1999). However, with inoculum it is possible to standardize the compounds formed during the fermentation with a direct effect on the quality of the cider (Ribéreau-Gayon et al. 1998).

Alcoholic fermentation converts the sugars to alcohol and carbon dioxide. It may occur through the indigenous microflora action by Saccharomyces sp., especially $S$. uvarum and $S$. cerevisiae, which are more adapted to the anaerobic conditions and alcohol content that are present in the fruit and in the processing environment (Michel and Bizeau 1988; Morrisey et al. 2004; Valles et al. 2007). Alcoholic fermentation may leave apple wine deficient in vitamins and amino acids for the development of bacteria in the first week of fermentation (Drilleau 1996). However, during the phase when the yeast dies, nutrients are released that act as growth factors in the development of lactic acid bacteria (King and Beelman 1986).

Malolactic fermentation (MLF) is a microbiological process that promotes the decarboxylation of L-malic acid (bicarboxylic) in L-latic acid (monocarboxylic). It is desirable for three reasons: a decrease in the acidity, an increase in sensory features and a contribution to microbiological stability (Versari et al. 1999; Liu 2002; Xu et al. 2005; Cañas et al. 2008). The average acidity of Brazilian apples is $3.6 \mathrm{~g} / \mathrm{L}$ (Paganini et al. 2004; Wosiacki et al. 2008). Oenococcus oeni is known as LAB, with a major capacity to develop malolactic fermentation in the modern fruit wine industry (Louvand-Funel 1995; Herrero et al. 1999; Liu 2002; Xu et al. 2005; Sánchez et al. 2010). Starter cultures of LAB are not employed to ensure its correct development in cider, as occurs in the wine industry (Herrero et al.
2001). Deeper knowledge of the complex microbial ecology during spontaneous MLF in traditional cider processing is therefore vital. Cider processing in Brazil began in the early 1970s, together with the first harvest of national apples. The production of the Gala and Fuji varieties represents $90 \%$ of total production and consequently apple must in Brazil is a mixture of these two varieties (ABPM 2011). Processing occurs in the summer, with temperatures between 25 and $35^{\circ} \mathrm{C}$. This temperature, combined with the addition of sulphur dioxide $(100-200 \mathrm{mg} / \mathrm{L})$ and active dry yeast inocula $(20-40 \mathrm{~g} / \mathrm{hL})$, results in a fast alcoholic fermentation (5-7 days) that promotes an aroma with 'yeasty' sensory notes, which must be normally corrected by the bottling industry. Before bottling, sugar may be added up to the maximum limit that is found in apples (ABPM 2011; Nogueira and Wosiacki 2010).

There are many works in the literature about the processing of apple wine and the factors that affect its quality. However, there are few studies about the behavior of the microorganisms responsible for apple must fermentation in Brazilian conditions, which differs greatly from that found in American and European processing. In this present article, the evaluation of the population dynamics of microorganisms used in Brazilian cider processing is presented with the intention of discussing the relationships between the physicochemical composition of the beverage, the various phases of fermentation, and the specific metabolites.

\section{MATERIALS AND METHODS}

\section{Raw material}

Samples (40 Kg) of commercial Gala apples, harvested in 2006/2007, both classified and unclassified, were supplied by the Boutin Group, Porto Amazonas/PR. The chemical reagents used were p.a. grade.

\section{Apple must processing}

The fruits were selected, cleaned in potable water, weighed, milled in a multi-processor (Metvisa Processor, type MPA) and put in the plastic screens. A set of five screens was arranged in a vertical pillage to extract the juice by two pressings (Eureka hydraulic press, Hoppe Ind. Ltd. Brazil), one at $1.0 \mathrm{kgf} / \mathrm{cm}$ for two minutes, followed by $4.0 \mathrm{kgf} / \mathrm{cm}$ for five minutes. The apple must was depectinized with enzyme (Pectinex- 
Batch $1201371 \mathrm{~L}$ ) at a concentration of $3.0 \mathrm{~mL} / \mathrm{hL}$, for $4 \mathrm{~h}$ at $25 \pm 2^{\circ} \mathrm{C}$ (Wosiacki et al. 1989). After this sedimentation time, the apple must was racked and divided in fermentors.

\section{Indigenous microorganisms in apple must}

The musts were used as source of microorganisms for the initial quantification of total yeast, nonSaccharomyces yeast and lactic bacteria acid.

\section{Apple wine processing}

The depectinized juice $(450 \mathrm{~mL})$ from each experiment was distributed in six Erlenmeyer flasks (500 mL), identified as $\mathrm{P}_{0}$ (control), $\mathrm{P}_{3}, \mathrm{P}_{10}$, $\mathrm{P}_{20}, \mathrm{P}_{30}$ and $\mathrm{P}_{45}$ (days of fermentation), respectively.

\section{Fermentation}

The fermentations were carried out as follows: (A) natural fermentation; (B) fermentation with inoculum of $S$. cerevisiae $(0.05 \%$, Arôme Plus, Pascal Biotech) that corresponded to approximately $6.00 \cdot 10^{6}$ cells $/ \mathrm{mL} ;(\mathrm{C})$ fermentation with inoculum of $S$. cerevisiae (Arôme Plus, AEB Goup) and $10 \mathrm{mg}$ of Oenococcus oeni that corresponded to $1.00 \cdot 10^{6}$ cells $/ \mathrm{mL}$ (Enolat DIR*01, Vêneto Mercantil). The yeast fermentations were conducted at room temperature with a variation between 24.9 to $30.7^{\circ} \mathrm{C}$, similar to industrial conditions.

\section{Fermentation rate}

Fermentation was monitored by weight loss caused by the release of $\mathrm{CO}_{2}$ (Bely et al. 1990; Roger et al. 2002) and the weight was determined every two hours at a sensitivity of $0.001 \mathrm{~g}$ for 45 days (fermentation time) at room temperature (24.9 to $\left.30.7^{\circ} \mathrm{C}\right)$. The $\mathrm{CO}_{2}$ production rate $\left(\mathrm{dCO}_{2} / \mathrm{dt}\right)$ was calculated by polynomial smoothing (Alberti et al. 2011).

\section{Total yeasts counting}

Total yeasts count were performed considering the colonies in a selective medium prepared with $39 \mathrm{~g}$ of PDA (Potato Dextrose Agar, Difco 213400) diluted in $1000 \mathrm{~mL}$ of distilled water. The material was sterilized in a retort (AV 13811, Phoenix). Tartaric acid (ACS-189, Ecibra) 1:10 in the concentration of $1.8 \%$ was added and the medium was poured into $90 \mathrm{~mm}$ diameter Petri dishes (J. Prolab). After solidification, the cold media were inoculated with $100 \mu \mathrm{L}$-sample and incubated at $28^{\circ} \mathrm{C}$ for $48 \mathrm{~h}$. The visible colonies were counted manually and the result expressed in $\mathrm{CFU} / \mathrm{mL}$ (Silva et al. 2010).

\section{Apiculate yeasts counting}

Selected medium was prepared in two stages. In the first, $11.75 \mathrm{~mL}$ of yeast extract (Biobrás, cod. 155-1) was diluted in $500 \mathrm{~mL}$ of distilled water and sterilized in an autoclave. In the second stage, the extract was prepared with $2.3 \mathrm{~g}$ of lysine, $20 \mathrm{~g}$ of agar-agar (Rea-tech), diluted in $500 \mathrm{~mL}$ of distilled water, warmed until complete dissolution in a microwave and sterilized in an autoclave. Both media were mixed together and $10 \mathrm{~mL}$ was poured into $90 \mathrm{~mm}$ Petri dishes and later, the solid media received $100 \mu \mathrm{L}$ of source of microorganisms. After the incubation at $28^{\circ} \mathrm{C}$ for $48 \mathrm{~h}$, the colonies were counted manually and the result expressed in CFU/Ml (Silva et al. 2010).

\section{Lactic bacteria counting}

Selective medium was prepared with $50 \mathrm{~g}$ of MRS agar (Lactobacilli MRS, Broth) diluted in $950 \mathrm{~mL}$ of distilled water and the $\mathrm{pH}$ was adjusted to 4.8 with concentrated phosphoric acid (Biotec). To this medium $20.0 \mathrm{~g}$ of agar-agar (Rea-Tech) was added and the volume was completed with doubledistilled water to make $1000 \mathrm{~mL}$. A solution of antibiotics was prepared using $20.0 \mathrm{mg}$ of actidione (Cycloheximide Sigma C1988-5G) and $5.0 \mathrm{mg}$ of oxine (8-quinolinol Sigma H6878-25G) diluted in $10.0 \mathrm{~mL}$ of distilled water and sterilized by filtering using sterile membrane of $0.45 \mu \mathrm{m}$. A $1.0 \mathrm{~mL}$ of the sample was introduced into a Petri plaque with $0.5 \mathrm{~mL}$ of antibiotic solution and 10.0 $\mathrm{mL}$ of the culture medium. The plaques were placed in anaerobic (Anaerobac, Probac do Brasil Ltd) jugs (Permution). After incubation for 8 days at $28^{\circ} \mathrm{C}$, the colonies were manually counted and expressed as CFU/mL (Silva et al. 2010).

\section{Physicochemical analysis}

The reducing sugars were quantified by the classic Somogyi (1945) and Nelson (1944) method. Sucrose was hydrlyzed with $\mathrm{HCl} 1 \mathrm{M}\left(50^{\circ} \mathrm{C} / 5\right.$ min). Glucose was quantified by the enzymatic method of glucose oxidase, and sucrose and fructose were calculated by difference. The results of glucose and fructose were confirmed by the enzymes kit (cod. 0139106, Roche). All the sugars were expressed in $\mathrm{g} / 100 \mathrm{~mL}$ (Tanner and Brunner 1985). The total acidity was determined by neutralization with $0.1 \mathrm{M} \mathrm{NaOH}$, with phenolphthalein as an indicator, and expressed as 
malic acid in $\mathrm{g} / 100 \mathrm{~mL}$ (IAL 2008). The volatile acidity was calculated as acetic acid and expressed as $\mathrm{g} / 100 \mathrm{~mL}$ (IAL 2008). The L-malic acid, Dlactic acid and L-lactic acid were quantified by the enzymes kit (L-Malic acid, cod. 10139068035 and D-Lactic, L-Lactic, cod. 11112821035, Roche). The ethyl alcohol content was determined by ebuliometry. The $\mathrm{pH}$ was determined by a $\mathrm{pH}$ meter (Tecnal $\mathrm{pH}$ digital micro processor, model TEC3-MP) and the total nitrogen content was determined by the Kjedhal method (IAL 2008).

\section{Statistical analysis}

Statistical descriptive analyses were carried out using Microsoft Excel 2007 software.

\section{RESULTS AND DISCUSSION}

\section{Indigenous microorganisms in apple must}

Commercial and unclassified apples were processed separately. The populations of total and apiculate yeast and LAB of the two apple juices were evaluated (Table 1). This process was repeated ten times with different batches of fruit for the fermentative and oxidative yeasts, and eight times for the LAB. In the fresh must, on the laboratory scale the initial apiculate yeast population was $1.13 \cdot 10^{4} \mathrm{CFU} / \mathrm{mL}$ but in the unclassified apples this reached up to $3.20 \cdot 10^{5}$ $\mathrm{CFU} / \mathrm{mL}$ due to contaminated fruits (Table 1). Similar values $\left(5.50 \cdot 10^{5} \mathrm{CFU} / \mathrm{mL}\right)$ were found in apple must by Nogueira et al. (2007). These counts could be explained because the processing of cider occurred in the summer with temperatures of around $25^{\circ} \mathrm{C}$ and also due to low acidity and the low tannin content of the raw material. It is usual to add sulphite as soon as the juice is extracted in order to eliminate undesirable microorganisms, but this procedure also affects non-Saccharomyces and some bacteria that contribute to the formation of pleasant flavors (Lea and Drilleau 2003).

The initial population of fermentative yeast in the apple must made with commercial apples was $4.31 \cdot 10^{3} \mathrm{CFU} / \mathrm{mL}$. When the must was obtained from unclassified fruits (those that were removed during the classification process due to defects, including contamination), the yeast population was higher, reaching $9.14 \cdot 10^{3} \mathrm{CFU} / \mathrm{mL}$. Nogueira et al. (2007) found higher values, between $3.00 \cdot 10^{4}$ and $6.50 \cdot 10^{4} \mathrm{CFU} / \mathrm{mL}$, in commercial and unclassified apples, respectively. $\mathrm{LAB}$ ranged from zero to $1.17 \cdot 10^{2} \mathrm{CFU} / \mathrm{mL}$ in the commercial apples. The populations of unclassified apples were similar, from zero to $1.41 \cdot 10^{2} \mathrm{CFU} / \mathrm{mL}$ (Table 1). These values could be higher depending on the stage of maturity, injury, or degree of contamination.

Table 1 - Natural microorganisms in fresh apple musts with technological interest in cider processing.

\begin{tabular}{lcccccc}
\hline \multicolumn{1}{c}{$\begin{array}{c}\text { Microorganisms, } \\
\text { CFU/mL }\end{array}$} & $\mathbf{c}$ Colony counting (CFU/mL) \\
\cline { 2 - 7 } Commercial apples & $\mathbf{N}$ & Min. & Average & Max. & SD & CV, \% \\
\hline Total apiculate yeast & 10 & $2.60 \cdot 10^{3}$ & $1.13 \cdot 10^{4}$ & $2.40 \cdot 10^{4}$ & $6.71 \cdot 10^{3}$ & 59.50 \\
Total fermentative yeast* & 10 & $1.00 \cdot 10^{2}$ & $4.31 \cdot 10^{3}$ & $2.02 \cdot 10^{4}$ & $6.64 \cdot 10^{3}$ & 153.84 \\
Total lactic acid bacteria (LAB) & 8 & Absent & $1.48 \cdot 10^{1}$ & $1.17 \cdot 10^{2}$ & $4.13 \cdot 10^{1}$ & 280.11 \\
\hline Unclassified apples** & & & & & & 152.91 \\
\hline Total apiculate yeast & 10 & $1.03 \cdot 10^{4}$ & $3.20 \cdot 10^{5}$ & $1.24 \cdot 10^{6}$ & $4.90 \cdot 10^{5}$ & 150.84 \\
Total fermentative yeast* & 10 & $7.80 \cdot 10^{1}$ & $9.14 \cdot 10^{3}$ & $4.27 \cdot 10^{4}$ & $1.38 \cdot 10^{4}$ & 196.44 \\
Total lactic acid bacteria (LAB) & 8 & Absent & $2.53 \cdot 10^{1}$ & $1.41 \cdot 10^{2}$ & $4.96 \cdot 10^{1}$ & 19.45
\end{tabular}

Note: (N) sampling number; (SD) standard deviation; (CV) coefficient of variation. (*) mainly Saccharomyces sp. (**) apples with injuries and morphological and phytopathological defects. $\mathrm{CV}$ values in rapport at indigenous yeast variation in apple.

\section{Apple must composition}

Table 2 showed the results of the apple must composition and alcoholic fermentation with three inoculums conditions: (A) indigenous yeast (natural), (B) inoculated with yeast, and (C) inoculated with yeast and lactic bacteria. The total reducing sugars, $111.83 \mathrm{~g} / 100 \mathrm{~mL}$ (glucose, fructose and sucrose) and the reducing sugar 80.75 $\mathrm{g} / 100 \mathrm{~mL}$ (glucose and fructose) in the apple must composition showed an adequate degree of ripening for apple wine processing (Paganini et al. 2004). According to Beech (1993), this apple must is classified as regular $(1047-1056 \mathrm{~m} / \mathrm{v})$. The total nitrogen content was considered a normal value (75-150 $\mathrm{mg} / \mathrm{L})$, in accordance with RibereauGayon (1998) and Alberti et al. (2011). The pH, total acidity and volatile acidity were similar to the apple must of the Gala variety evaluated by 
Wosiacki et al. (2008). The malic acid content (2.6 $\mathrm{g} / \mathrm{L}$ ), the main organic acid found in the apples, was considered low in comparison with the European industrial apple must; around $4.5 \mathrm{~g} / \mathrm{L}$ (Drilleau 1996). This was because Brazilian apple production consisted of the fruits that were developed and genetically improved for immediate consumption. As far as these varieties were concerned, they consisted of 95\% of Brazilian production, being 55\% Gala and 40\% Fuji (ABPM 2011).

Table 2 - Composition of apple must (zero time: $\mathrm{P}_{0}$ ) and during natural fermentation (1), with Saccharomyces cerevisiae (Ârome Plus) inoculation (2) and with Saccharomyces cerevisiae (Ârome Plus) and Oenococcus oeni (Enolat DIR*01) inoculation (3).

\begin{tabular}{|c|c|c|c|c|c|c|c|c|c|c|c|c|c|c|c|}
\hline \multirow{3}{*}{ Analysis } & \multicolumn{15}{|c|}{ Fermentative microflora and fermentation time (days) } \\
\hline & \multirow{2}{*}{$\begin{array}{c}\begin{array}{c}\text { Apple } \\
\text { must }\end{array} \\
\mathbf{P}_{\mathbf{0}} \\
\end{array}$} & \multicolumn{4}{|c|}{$\begin{array}{l}\text { Indigenous microflora } \\
\text { (natural fermentation) }\end{array}$} & \multicolumn{5}{|c|}{$\begin{array}{c}\text { S. cerevisiae } \\
\text { Inoculation }\end{array}$} & \multicolumn{5}{|c|}{$\begin{array}{c}\text { S. cerevisiae } \text { and } \\
\text { O. oeni inoculation }\end{array}$} \\
\hline & & 3 & 10 & 30 & 45 & 3 & 10 & 20 & 30 & 45 & 3 & 10 & 20 & 30 & 45 \\
\hline $\mathrm{TRS} /(\mathrm{g} / \mathrm{L})$ & 111.83 & 80.77 & 21.42 & 04.61 & 02.89 & 47.50 & 1.53 & 0.76 & 0.39 & 0.33 & 46.34 & 1.47 & 0.68 & 0.58 & 0.59 \\
\hline $\mathrm{RS} /(\mathrm{g} / \mathrm{L})$ & & & & & & & 1.52 & & & & & 1.43 & & & \\
\hline Fructose $/(\mathrm{g} / \mathrm{L})$ & 4.61 & 35.95 & 18.19 & 2.81 & 2.70 & 36.89 & 1.51 & 0.59 & 0.17 & 0.10 & 33.47 & 1.42 & 0.63 & 0.34 & 0.18 \\
\hline & 1.08 & 31.00 & & 1.7 & & & 0.00 & & & & 5.65 & 0.03 & & & \\
\hline Glu & & 13 & & 0.02 & & & 0.01 & & 0.01 & 0.01 & 7.23 & 0.01 & 0.01 & 0. & 0.01 \\
\hline & & 20 & 4.90 & 5.60 & 5.60 & 3.75 & 6.50 & 6.20 & 6.50 & 6.35 & 3.90 & 6.55 & 6.30 & 6.20 & 6.50 \\
\hline & & & & 30 & 90 & 60 & 50 & 110 & & & 80 & 60 & 120 & 130 & 120 \\
\hline $\mathrm{SD} /(1$ & .00 & 56 & 5.12 & 3.84 & 3.84 & 3.84 & 4.48 & 6.40 & 3.84 & 3.85 & -- & -- & -- & -- & -- \\
\hline $\mathrm{pH}$ & & & & 3.48 & 3.42 & 3.96 & 4.22 & & 4.06 & 3.82 & 3.89 & 4.04 & 4.02 & 4.10 & 3.80 \\
\hline & 2.65 & 2.05 & & 5.08 & 6.25 & 2.66 & 1.99 & 2.20 & 2.30 & 3.20 & 2.54 & 2.12 & 2.58 & 2.36 & 2.98 \\
\hline Malic & 2.60 & 2.17 & 0.43 & 0.01 & 0.005 & 1.80 & 0.36 & 0.05 & $* * *$ & $* * *$ & 2.40 & 0.02 & 0.01 & $* *$ & \\
\hline Volatile aci & 0.72 & 0.74 & 0.56 & 0.82 & 1.27 & 0.64 & 0.64 & 0.83 & 0.97 & 0.91 & 0.52 & 0.66 & 1.17 & 1.06 & 0.91 \\
\hline & $* * *$ & 0.20 & 3.06 & 4.25 & 4.97 & 0.22 & 0.99 & 1.37 & 1.33 & 2.29 & 0.18 & 1.44 & 2.05 & 2.06 & 2.07 \\
\hline D-lactic acid/(g/L) & $* * *$ & -- & $* * *$ & -- & $* * *$ & -- & $* * *$ & -- & -- & $* * *$ & $* * *$ & -- & $* * *$ & $* * *$ & $* * *$ \\
\hline
\end{tabular}

Note: (TRS) total reducing sugar; (RS) reducing sugar; (SD) sulphur dioxide; (--) not analyzed; (***) trace.

\section{Natural fermentation}

The process of natural fermentation is not used in Brazilian apple wine processing, but it is still in use in France, Spain and Ireland (Beech 1994; Michel and Bizeau 1988; Lea and Drilleau 2003; Nogueira and Wosiacki 2010). In France, the alcoholic fermentation rate is slow and may exceed 60 days. This slow and natural fermentation is responsible for the formation of fruity and floral aromas and allows a better organization of unit operations, such as maintaining residual sugar (Lea and Drilleau 2003).

The natural fermentation of the apple must of the Gala variety can be seen in Figure 1A. Microbial succession is a reflection of microbial interactions, intrinsic growth factors and resistance to inhibitory environmental conditions, such as competition for nutrients and extreme acidic environment (Sánchez et al. 2010). The fermentative yeast (Saccharomyces $\mathrm{sp}$.) had an initial population of $4.25 \cdot 10^{4} \mathrm{CFU} / \mathrm{mL}$ and a similar value was found by Lequéré and Drilleau (1998) in French natural apple wine fermentation. The yeasts presented a rapid growth (Fig. 1A) up to a maximum population of $7.10 \cdot 10^{6} \mathrm{CFU} / \mathrm{mL}$ and then declined to $2.27 \cdot 10^{6} ; 1.95 \cdot 10^{5}$ and $3.15 \cdot 10^{3} \mathrm{CFU} / \mathrm{mL}$ after 20,30 and 45 days of processing, respectively. After 20 days of fermentation, $90 \%$ of fermentable sugars were removed. This final residue of sugar was slowly fermented, which could be explained by the toxins released by other microorganisms (Ribereau-Gayon et al. 1998), or by low resistance to ethanol (> 5.0\%) (Lafon-Lafourcade et al. 1984).

In the growth phase during the first three days, 30 $\mathrm{mg} / \mathrm{L}$ of nitrogen compounds were consumed by the non-Saccharomyces yeast. During the next seven days, $70 \mathrm{mg} / \mathrm{L}$ of total nitrogen were used due to the growth phase of Saccharomyces sp. (Fig. 1A). In the fermentation with inoculum of commercial yeast, and the fermentation with commercial yeast and LAB, between 90 to 100 $\mathrm{mg} / \mathrm{L}$ of total nitrogen were consumed during the growth phase (3-5 days). After 30 days of fermentation, a meaningful release of nitrogen compounds was observed (Table 2), indicating autolysis process (Patynowski et al. 2002). 


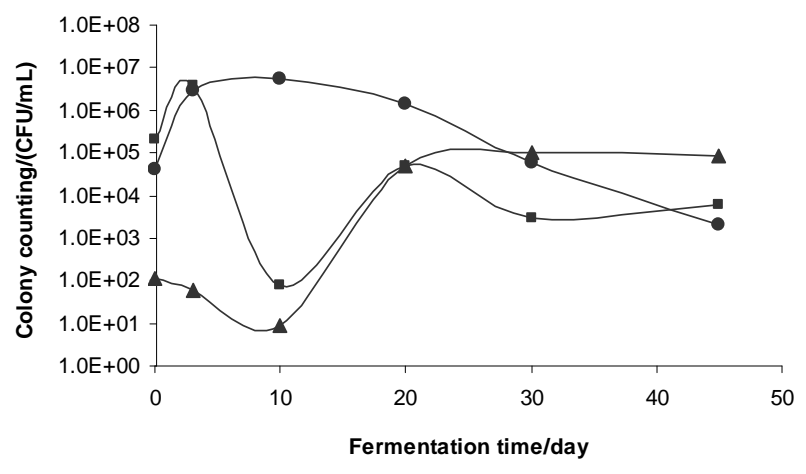

(A)

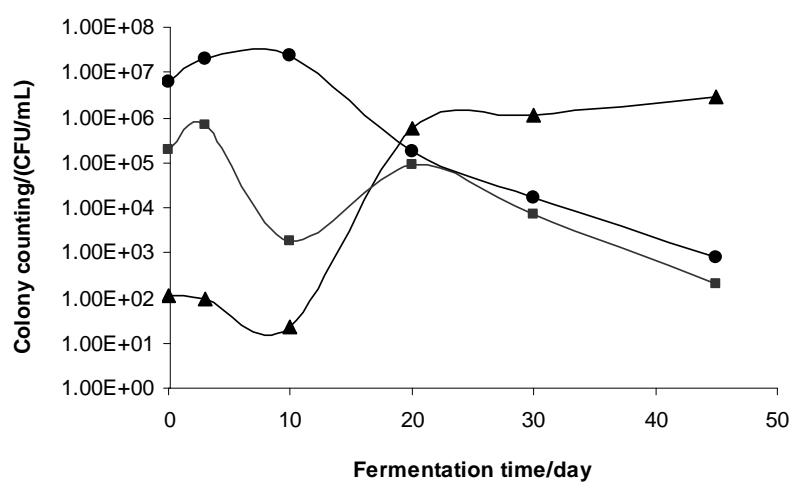

(B)

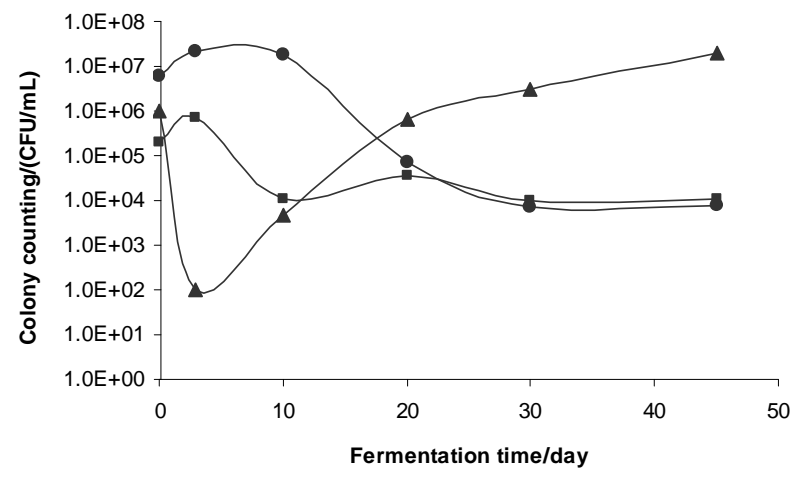

(C)

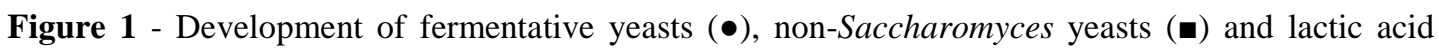
bacteria ( $\boldsymbol{\Delta})$ during fermentation (a) natural, (b) with the inoculum of $S$. cerevisiae (Arôme plus) and (c) with the inoculum of S. cerevisiae (Arôme plus) and Oenoccocus oeni (enolate DIR) in the processing of cider. Note: each point represents the average of two fermentations.

Apiculate yeasts, known as non-Saccharomyces, presented an initial population $\left(2.00 \cdot 10^{5} \mathrm{CFU} / \mathrm{mL}\right)$, which was larger than the fermentative yeast $\left(6.00 \cdot 10^{4} \mathrm{CFU} / \mathrm{mL}\right)($ Table 3$)$. Apiculate yeasts are recognized by esters and alcohol synthesis, which promote fruity and floral aromas in cider. This is regarded as a criterion for selecting suitable yeast strains (Bilbao et al. 1997; Lea and Drilleau 2003; $\mathrm{Xu}$ et al. 2006). The growth phase reached the maximum population $\left(3.78 \cdot 10^{6} \mathrm{CFU} / \mathrm{mL}\right)$ after three days of fermentation. After this, a decline phase of apiculate yeast was observed due to the growth of Saccharomyces sp. (Fig. 1A), a fact already observed by Martinez et al. (1989). According to Fleet (1990), this inhibition may simply reflect a low capacity to survive in the presence of alcohol. However, in Figure 1A, a new growth phase could be observed after the decline of the Saccharomyces sp phase.

Other factors that may reduce the permanence time of the apiculate yeast during alcoholic fermentation are the availability of nutrients, temperature, inoculates of Saccharomyces, sulphur dioxide and processing technology (Fleet 1990; Romano et al. 1997; Charoenchai et al. 1998; Pina et al. 2004). However, Nissen and Arneborg (2003) mentioned that the apiculate yeast inhibition occurred due to the high density of the viable Saccharomyces sp cells. The mechanism of cell-cell contact could be explained by the new growth phase of apiculate yeast when the $S$. cerevisiae began the cell death phase. The new growth was also due to the release of nutrients from cell autolysis. This situation was observed after the tenth day of fermentation (Fig. 1A). However, a second decline phase of apiculate yeast (Fig. 1A) was observed, possibly due to the competition for nutrients with LAB in a medium with approximately $6.0^{\circ} \mathrm{GL}$, considered to be a limit value for survival (Gil et al. 1996).

The indigenous LAB population $\left(1.00 \cdot 10^{2}\right.$ $\mathrm{CFU} / \mathrm{mL}$ ) in apple must was similar to that 
reported by Drilleau (1996) in apple epicarp. In Figure 1A, the lactic acid bacteria population showed a declined phase on the first day of fermentation. This could be due to competition for nutrients and toxic compounds secreted by the yeasts during their growth (Osborne and Edwards 2007). After 10 days of fermentation, the LAB population was $8.5 \mathrm{CFU} / \mathrm{mL}$. Therefore, due to the death of the fermentative yeast and its cellular autolysis, the release of nutrients stimulated the growth of bacteria (Patynowski et al. 2002). After 20 days of fermentation, the population increased to $4.1 \cdot 10^{4} \mathrm{CFU} / \mathrm{mL}$, remaining stable until the end of the experiment (Fig. 1 and Table 3).

The initial $\mathrm{pH}$ of apple must was 4.03 and after 45 days of natural fermentation, it reduced to 3.42 . The total acidity increased from 2.65 to $6.25 \mathrm{~g} / \mathrm{L}$, mainly due to L-lactic acid production by LAB (Table 2). The malic acid of apple must $(2.60 \mathrm{~g} / \mathrm{L})$ was metabolized during alcoholic fermentation, decreasing to 0.43 and to $0.005 \mathrm{~g} / \mathrm{L}$ after 10 and 45 days of fermentation, respectively. D-lactic acid was found in small quantity, indicating that malic acid was mainly converted into L-lactic acid (Table 2). The sulphur dioxide produced by the yeasts varied from 2.56 to $5.12 \mathrm{~g} / \mathrm{L}$ (Table 2). These concentrations did not affect, or inhibit the LAB as also observed by Osborne and Edwards (2006).

\section{Fermentation with yeast inoculation}

The inoculation of active dry yeast is a normal operation in Brazilian cider processing. In the experiments with $S$. cerevisiae (Arôme Plus) inoculum $\left(6.02 \cdot 10^{6} \mathrm{CFU} / \mathrm{mL}\right)$, after just 1.81 days of fermentation, the population reached the maximum of $2.43 \cdot 10^{7} \mathrm{CFU} / \mathrm{mL}$ (Fig. 1B). Similar results were obtained by Zardo et al. (2008) and Nogueira et al. (2008). This population was higher than the maximum observed in natural fermentation $\left(7.10 \cdot 10^{6} \mathrm{CFU} / \mathrm{mL}\right)$, due to the following factors: the process of strain selection; genetic improvement, and the technology of dry active cells (Soubeyrand et al. 2005; Pellet et al. 2006; Nogueira et al. 2008).

The yeast population of $10^{7} \mathrm{CFU} / \mathrm{mL}$ remained stable until the tenth day of fermentation, when $98.63 \%$ of total reduced sugar was fermented for the production of $6.5 \%$ of alcohol $(\mathrm{v} / \mathrm{v})$ (Table 2). Glucose is the first sugar consumed by Saccharomyces $\mathrm{sp}$. in the alcoholic fermentation of apple juice, in a ratio of 4:1 (GLU:FRU) in function of the participation of hexokinase PI and PII that promote the phosphorylation of glucose and fructose, respectively. However, in a ratio of $3: 1$, glucokinase reacts exclusively with the glucose (D'Amore et al. 1989). The sucrose content decreased rapidly (86.5\%) after three days of fermentation due to hydrolysis releasing glucose and fructose. In the presence of sucrose, Saccharomyces starts the synthesis and release of invertase (Walker 1998; Herrero et al. 1999). However, in natural fermentation, the major consumption was of fructose, while glucose and sucrose remained stable during the first three days, which showed a lag phase for indigenous yeast adaptation. After this period, the sugar consumption was higher (Table 2). After 10 days, total yeast Saccharomyces sp. presented a phase of decline, and after 45 days the population was ca. $10^{3} \mathrm{CFU} / \mathrm{mL}$.

Nitrogen consumption during the yeast growth was around $90 \mathrm{mg} / \mathrm{L}$; similar value was observed by Remize et al. (2006) in wine. Cellular autolysis greatly affected the nitrogen compound concentration, increasing from $60\left(10^{\text {th }}\right.$ day $)$ to 110 $\mathrm{mg} / \mathrm{L}$ (20 ${ }^{\text {th }}$ day). Lurton et al. (1989) have also reported the increase in nitrogen content during yeast autolysis in wines. The production of sulphur dioxide by inoculated commercial yeast was higher than in natural fermentation, but the content was too low to affect the growth of yeasts, or LAB (Würdig 1985; Reguant et al. 2005).

During the rapid development of fermentative yeasts, inhibition similarly peaked more quickly (Fig. 1B), damaging the multiplication of the same at the beginning of fermentation. The maximum population reached $8.20 \cdot 10^{5} \mathrm{CFU} / \mathrm{mL}$, which was less than during natural fermentation (Table 3). Thus, the use of inoculum of $S$. cerevisiae immediately after obtaining the apple must, might prevent the initial development of nonSaccharomyces, and therefore, impaired the formation of typical cider aromas. Inoculum of $S$. cerevisiae after two, or three days of apple must extraction might be sufficient for the proliferation of apiculate yeasts, and thus would allow the product to develop fruity and flowery aromas. The second growth of apiculate yeasts after the decline of fermentative yeasts was much lower than that observed in natural fermentation, possibly due to the fact that the ethanol content at this point was already $6.5^{\circ} \mathrm{GL}$, the tolerance limit for these microorganisms. 
The population of LAB remained low until the loss of viability of yeast fermentation (Fig. 1B). After the $10^{\text {th }}$ day of fermentation the population, started a new growth to reach $1.14 \cdot 10^{6} \mathrm{CFU} / \mathrm{mL}$ in 20 days, remaining stable until the end of the experiment (45 days). The population of LAB in this medium was higher than the natural fermentation, which could be explained by the higher amount of nutrients released by cell autolysis. Alexandre et al. (2001) observed that during the autolysis of yeast, amino acids such as asparagine, arginine, $\alpha$-aminobutyric acid, histidine, leucine, threonine and serine appeared in the fermentation medium. The appearance of serine and threonine was related to cell wall degradation, since the cell wall was rich in these amino acids.

The LAB metabolized malic acid from the apples, which decreased from 2.60 on the $1^{\text {st }}$ day to 0.36 $\mathrm{g} / \mathrm{L}$ and in traces on the $10^{\text {th }}$ and $45^{\text {th }}$ days, respectively. According to Herrero et al. (1999), this was due to the decarboxylation of malic acid during fermentation. Concurrently, the values of L-lactic acid increased during the same period from zero to 0.99 and $2.29 \mathrm{~g} / \mathrm{L}$, respectively (Table 2). The $\mathrm{pH}$ decreased from 4.03 to 3.82 and the total acidity increased from 2.65 to $3.20 \mathrm{~g} / \mathrm{L}$. The fermentation with inoculation was 2.3 times quicker than the natural fermentation (Table 3 ).

Table 3 - Parameters of fermentation of apple must (cv. Gala), with initial microflora: (1) natural, (2) with $S$. cerevisiae (Arôme plus) inoculum and (3) with S. cerevisiae (Arôme plus) and Oenoccocus oeni (enolate DIR) inoculum.

\begin{tabular}{|c|c|c|c|}
\hline \multirow[b]{2}{*}{ Parameters } & \multicolumn{3}{|c|}{ Initial microflora of fermentation } \\
\hline & $\begin{array}{l}\text { Indigenous microflora } \\
\text { (natural fermentation) }\end{array}$ & $\begin{array}{l}\text { S. cerevisiae } \\
\text { inoculation }\end{array}$ & $\begin{array}{l}\text { S. cerevisiae and } \\
\text { O. oeni inoculation }\end{array}$ \\
\hline $\mathrm{IP}_{\text {Saccharomyces }} /(\mathrm{CFU} / \mathrm{mL})$ & $6.00 \cdot 10^{4}$ & $6.02 \cdot 10^{6}$ & $6.02 \cdot 10^{6}$ \\
\hline $\mathrm{MP}_{\text {Saccharomyces }} /(\mathrm{CFU} / \mathrm{mL})$ & $\begin{array}{l}7.10 \cdot 10^{6} \\
(7 \text { days })\end{array}$ & $\begin{array}{l}2.43 \cdot 10^{7} \\
(3 \text { days })\end{array}$ & $\begin{array}{l}2.40 \cdot 10^{7} \\
(3 \text { days })\end{array}$ \\
\hline $\mathrm{IP}_{\text {Apiculate }} /(\mathrm{CFU} / \mathrm{mL})$ & $2.00 \cdot 10^{5}$ & $2.00 \cdot 10^{5}$ & $2.0 \cdot 10^{5}$ \\
\hline $\mathrm{MP}_{\text {Apiculate }} /(\mathrm{CFU} / \mathrm{mL})$ & $\begin{array}{l}3.78 \cdot 10^{6} \\
(3 \text { days })\end{array}$ & $\begin{array}{l}8.20 \cdot 10^{5} \\
(4 \text { days })\end{array}$ & $\begin{array}{l}8.50 \cdot 10^{5} \\
(4 \text { days })\end{array}$ \\
\hline $\mathrm{IP}_{\text {lactic bactéria }} /(\mathrm{CFU} / \mathrm{mL})$ & $1.00 \cdot 10^{2}$ & $1.00 \cdot 10^{2}$ & $1.00 \cdot 10^{6}$ \\
\hline $\mathrm{MP}_{\text {lactic bactéria }} /(\mathrm{CFU} / \mathrm{mL})$ & $\begin{array}{l}4.13 \cdot 10^{4} \\
(20 \text { days })\end{array}$ & $\begin{array}{l}1.14 \cdot 10^{6} \\
(20 \text { days })\end{array}$ & $\begin{array}{c}6.70 \cdot 10^{5} \\
(20 \text { days })^{*}\end{array}$ \\
\hline Vmax./(g/L)/(d) & 2.65 & 6.11 & 6.20 \\
\hline Time to $\mathrm{Vmax} /(\mathrm{d})$ & 3.0 & 1.7 & 1.6 \\
\hline Final sugars $* * /(d)$ & $>45$ & 12 & 12 \\
\hline
\end{tabular}

Note: IP: initial population; MP: maximum population; $\left({ }^{*}\right)$ continued to rise, reaching $5.00 \cdot 10^{7}$ after 45 days, Vmax: maximum fermentation rate; $(* *)$ total consumption of sugars.

Fermentation with yeast and lactic acid bacteria inocula

In the third experiment, strains of S. cerevisiae and $O$. oeni were simultaneously inoculated in apple must. In cider, as in wine, Lactobacillus and Oenococcus have been described as the predominant genera during MLF (Cabranes et al. 1991; Dueñas et al. 1994; Sánchez et al. 2010). The kinetic behavior of S. cerevisiae and apiculate yeasts was similar to that observed in the experiment where only $S$. cerevisiae was inoculated. The consumption of sugar and ethanol production was similar to that described in the experiment with only yeast inoculum (Table 2).

The population of LAB inoculated into the apple must $\left(1.00 \cdot 10^{6} \mathrm{CFU} / \mathrm{mL}\right)$ decreased and remained low until the end of alcoholic fermentation (Fig.
1C). With the autolysis of yeasts demonstrated by the increase of nitrogen from $60 \mathrm{mg} / \mathrm{L}$ at 10 days of fermentation to $120 \mathrm{mg} / \mathrm{L}$ after 20 days, the bacterial population started growing. The growth phase of yeast possibly provided a selection of more resistant strains of bacteria in the medium. However, the population observed at 20 days was $6.7010^{5} \mathrm{CFU} / \mathrm{mL}$, which was lower than the experiment with the inoculum of $S$. cerevisiae $\left(1.14 \cdot 10^{6} \mathrm{CFU} / \mathrm{mL}\right)$. This could be due to the LAB characteristic of $O$. oeni (enolate DIR*01) in apple wine fermentation. However, the bacteria continued to grow, and at the end of 45 days, reached a population of more than $10^{7} \mathrm{CFU} / \mathrm{mL}$ (Fig. 1C). Thus, the inoculum of LAB simultaneously with the yeast inoculum was of interest in relation to the control of malolactic 
fermentation. The other physicochemical (Table 2) and kinetic (Table 3) parameters were similar to those observed in the experiment with the $S$. cerevisiae yeast inoculum.

\section{CONCLUSIONS}

During this study, the characteristics of three groups of microorganisms in mixed cultures that could participate in the quality of apple wine and ciders were observed. Similar characteristics were observed in the growth phase during all the experiments. The differences were $(\mathrm{A})$ in the fermentation rate by the indigenous and inoculated yeasts, and (B) in the intensity of competition between the microorganisms, depending on the inoculum. The non-Saccharomyces yeasts, naturally present in apples, grew rapidly in the early stage of fermentation. But in all the experiments, they were inhibited at much lower populations by competing with Saccharomyces yeast. In all the three situations, during the growth of yeasts in fermentation, the LAB had their growth inhibited. After the loss of viability of yeast, LAB were stimulated to new growth. With the inoculum of LAB in apple must, after the decline of the yeasts, the new growth of LAB was significantly higher. This could be a way to control the quality of malolactic fermentation in brut, or sec ciders. These results are important for increased knowledge about cider processing and more research is required in this area in order to improve the quality of Brazilian cider.

\section{ACKNOWLEDGEMENTS}

The authors are deeply grateful to $\mathrm{CNPq}$ and CAPES for scholarships and grants received, as well as to the State University of Ponta Grossa (UEPG) for providing infrastructural conditions for the development of this research and to the Apple Research Group (GTM) for all the help provided.

\section{REFERENCES}

Alberti A, Wosiacki G, Nogueira A. Apple wine processing with nitrogen contents. Braz Arch Biol Technol. 2011; 54(1):10-18.
Alexandre H, Heintz D, Chassagne D, GuillouxBenatier, Charpentier C, Feuillzy M. Protease A activity and nitrogen fractions released during alcoholic fermentation and autolysis in enological conditions. J Indust Microbiol Biotech. 2001; 26(4):235-240.

Associação Brasileira de Produtores de Maçã (ABPM) [homepage on the internet]. Fraiburgo: Associação Brasileira de Produtores de Maçã; [cited 2011 Feb. 08]. Dados estatísticos sobre a cultura da macieira. Available from: http://www.abpm.org.br.

Beech FW. Yeasts in cider-making. In: Rose $\mathrm{AH}$, Harrison JS, editors. The Yeasts, Yeast Technology. Second edition. Academic Press Limited; 1993. pp. 169-213.

Bely M, Sablayrolles JM, Barre P. Automatic detection of assimilable nitrogen deficiencies during alcoholic fermentation in oenological conditions. J Ferment Bioengineer. 1990; 70(4):246-252.

Bilbao A, Irastorza A, Duenas M, Fernandez K. The effect of temperature on the growth of strains of Kloeckera apiculata and Saccharomyces cerevisiae in apple juice fermentation. Lett Appl Microbiol. 1997; 24(1):37-39.

Cabranes C, Mangas JJ, Blanco D. Selection and biochemical characterisation of Saccharomyces cerevisiae and Kloeckera apiculata strains isolated from spanish cider. J Inst Brew. 1997; 103(3):165170.

Cabranes C, Moreno J, Mangas JJ. Aspectos microbiológicos y bioquímicos de la elaboración de sidra natural en lagares asturianos. Alimentaria. 1991; 221: 63-69.

Charoenchai C, Fleet GH, Henschke PA. Effects of temperature, $\mathrm{pH}$, and sugar concentration on the growth rates and cell biomass of wine yeasts. Am J Enol Vitic. 1998; 49(3):283-288.

Cañas PMI, Romero EG, Alonso SG, Herreros MLLP. Changes in the aromatic composition of Tempranillo wines during spontaneous malolatic fermentation. $J$ Food Compos Anal. 2008; 21: 724-730

Coton E, Coton M, Levert D, Casaregola S, Sohier D. Yeast ecology in French cider and black olive natural fermentations. I J Food Microbiol. 2006; 108(1):130.

D'Amore T, Russell, I., Stewart, G.G. Sugar utilization by yeast during fermentation. J Ind Microbiol. 1989; 4:315-324.

Drilleau JF. La cidrerie. In: Bourgeois CM, Larpent JP, editors. Microbiologie alimentaire, aliments fermentés et fermentations alimentaires. Paris: Lavoisier; 1996. pp 138-61.

Duenas M, Irastorza A, Fernandez K, Bilbao A, Huerta A. Microbial populations and malolactic fermentation of apple cider using traditional and modified methods. J Food Sci. 1994; 59(5):1060-1064. 
Fleet GH. Growth of yeasts during wine fermentations. J Wine Res. 1990; 1(3):211-223.

Gil JV, Mateo JJ, Jiménez M, Huerta T, Pastor A. Aroma compounds in wine as influenced by apiculate yeasts. J Food Sci. 1996; 61(6):1247-1249+66.

Herrero M, De la Roza C, Garcia LA, Díaz M. Simultaneous and sequential fermentations with yeast and lactic acid bacteria in apple juice. J Indust Microbiol Biotech. 1999; 22(1):48-51.

Herrero M, Laca A, Garcia LA, Diaz M. Controlled malolactic fermentation in cider using Oenococcus oeni immobilized in alginate beads and comparison with free cell fermentation. Enzyme Microbial Technol. 2001; 28(1):35-41.

IAL. Métodos físicos e químicos para análise de alimentos. In: IAL, editor. Normas Analíticas. 4 ed. São Paulo: Instituto Adolfo Lutz; 2008.

King SW, Beelman RB. Metabolic interactions between Saccharomyces cerevisiae and Leuconostoc oenos in a model grape juice/wine system. Am J Enol Vitic. 1986; 37(1):53-60.

Lafon-Lafourcade S, Geneix C, Ribereau-Gayon P. Inhibition of alcoholic fermentation of grape must by fatty acids produced by yeasts and their elimination by yeast ghosts. Appl Environ Microbiol. 1984; 47(6):1246-1249.

Le Quéré JM, Drilleau JF. Microbiologie et technologie du cidre. Revue des Enologues. 1998; (88):17-20.

Lea A, Drilleau J-F. Cider-making. In: Lea A, editor. Fermented Beverage Production. London: 2003. p. 59-87.

Liu S-Q. Malolactic fermentation in wine - Beyond deacidification. J Appl Microbiol. 2002; 92(4):589601.

Lonvaud-Funel A. Microbiology of the malolactic fermentation: Molecular aspects. FEMS Microbiol Lett. 1995; 126(3):209-214.

Lurton L, Segain JP, Feuillat M. Étude de la proteolyse au cours de l'autolyse de levures en millieu acide. Sci Aliment. 1989; 9: 111-124.

Martinez J, Millan C, Ortega, JM. Growth of natural flora during the fermentation of inoculated musts from "Pedro Ximenez" grape. S Afr J Enol Vitic. 1989; 10: 31-35.

Michel A, Bizeau C. Flore levurienne presente dans les cidreries de l'ouest de la France. Sciences des Aliments. 1988; 8(3):359-368.

Morrisey WE, Davenport B, Dobson BADW, Querol A, The role of indigenous yeast in traditional Irish cider fermentations. J Appl Microbiol. 2004; 97: 647-655.

Nelson N. A photometric adaptation of the Somogyi method for determination of glucose. J Biol Chem. $1944 ; 153: 375-380$.

Nissen P, Arneborg N. Characterization of early deaths of non-Saccharomyces yeast in mixed cultures with Saccharomyces cerevisiae. Arch Microbiol. 2003; 180: 257-263.
Nogueira A, Alberti A, Dantas AP, Mongruel C, Wosiacki G, Influência da cepa de Saccharomyces cerevisiae na cinética de fermentação do vinho de maçã. Rev Bras Tecnol Agroindustrial. 2007; 1: 3036.

Nogueira A, Guyot S, Marnet N, Le Quere JM, Drilleau JF, Wosiacki G. Effect of alcoholic fermentation in the content of phenolic compounds in cider processing. Braz Arch Biol Technol. 2008; 15: 1025 1032.

Nogueira A, Wosiacki G. Sidra. In: Filho WV, editor. Tecnologia de Bebidas Alcoólicas. São Paulo: Blucher; 2010. pp 113-142.

Osborne JP, Edwards CG. Inhibition of malolactic fermentation by Saccharomyces cerevisiae during alcoholic fermentation under low and high conditions: a study in synthetic media. Aust J Grape Wine Res. 2006; 12: 69-78.

Osborne JP, Edwards CG. Inhibition of malolactic fermentation by a peptide produced by Saccharomyces cerevisiae during alcoholic fermentation. Int J Food Microbiol. 2007; 118(1):2734.

Paganini C, Nogueira A, Denardi F, Wosiacki G. Aptidão industrial de seis cultivares de maçã (dados da safra 2001/2002). Ciênc Agrotec. 2004; 28(6):1336-1343.

Patynowski RJ, Jiranek V, Markides AJ. Yeast viability during fermentation and sur lie ageing of a defined medium and subsequent growth of Oenococcus oeni. Aust J Grape Wine Res. 2002; 8(1):62-69.

Pillet O, Ortiz-Julien A, Salmon JM. Réduire les risques d'arrêt de fermentation: le rôle protecteur des stérols pendant la phase de rehydratation des levures sèches actives. Revue des Enologues. 2006; 120: 25-27.

Pina C, Santos C, Couto JA, Hogg T. Ethanol tolerance of five non-Saccharomyces wine yeasts in comparison with a strain of Saccharomyces cerevisiae - influence of different culture conditions. Food Microbiol. 2004; 21: 439-447.

Reguant C, Carreté R, Bordons A, Constantí M. Population dynamics of Oenococcus oeni strains in a new winery and the effect of SO2 and yeast strain. FEMS Microbiol Lett. 2005; 246(1):111-117.

Remize F, Gaudin A, Kong Y, Guzzo J, Alexandre H, Krieger S, et al. Oenococcus oeni preference for peptides: Qualitative and quantitative analysis of nitrogen assimilation. Arch Microbiology. 2006; 185(6):459-469.

Ribereau-Gayon PD, D.; Donèche, B.; Lonvaud, A. Traité D'Oenologie. Microbiologie du Vin Vinifications. Paris: Dunod; 1998.

Roger J-M, Sablayrolles J-M, Steyer J-P, BellonMaurel V. Pattern analysis techniques to process fermentation curves: application to discrimination of enological alcoholic fermentations. Biotechnol Bioeng. 2002; 79(7):804-815. 
Romano P, Suzzi G, Comi G, Zironi R, Maifreni M. Glycerol and other fermentation products of apiculate wine yeasts. J Appl Microbiol. 1997; 82(5):615-618.

Sánchez A, Rodríguez R, Coton M, Coton E, Herrero M, García LA, et al. Population dynamics of lactic acid bacteria during spontaneous malolactic fermentation in industrial cider. Food Res Int. 2010; 43(8):2101-2107.

Silva N, Junqueira VCA, Silveira N, Taniwaki M, Santos R, Gomes R. Métodos de análise microbiológica de alimentos. 4th ed. São Paulo: Varela; 2010.

Somogyi M. A new reagent for the determination of sugars. J Biol Chem. 1945; 160:61-68.

Soubeyrand V, Luparia V, Williams P, Doco T, Vernhet A, Ortiz-Julien A, et al. Formation of Micella Containing Solubilized Sterols during Rehydration of Active Dry Yeasts Improves Their Fermenting Capacity. J Agric Food Chem. 2005; 53(20):8025-8032.

Tanner H, Brunner, H.R. Getränke Anlytik Untersuchungsmethode für dia Labor- und Betriebspraxis. Wädesnwill: Verlag Helles; 1985.

Valles BS, Bedriñana RP, Queipo AL, Alonso JJM. Screening of cider yeasts for sparkling cider production (Champenoise method). Food Microbiol. 2008; 25(5):690-697.

Valles BS, Bedriñana RP, Tascón NF, Simón AQ, Madrera RR. Yeast species associated with the spontaneous fermentation of cider. Food Microbiol. 2007; 24(1):25-31.
Versari A, Parpinello GP, Cattaneo M. Leuconostoc oenos and malolactic fermentation in wine: A review. J Indust Microbiol Biotech. 1999; 23(6):447-455.

Walker GM. Yeast physiology and bitechnology. Scotland: John Wiley \& Sons; 1998.

Wosiacki G, Namiuchi NN. Stability of clarified apple juice. part 1 - processing of apple juice. Arq Biol Tecnol. 1989; 32(4):775-786.

Wosiacki G, Nogueira A, Silva NCC, Denardi F, Vieira RG. Quality profile of samples of 139 apples cultivars harvested in Brazil from 1982 to 2006. Acta Alimentaria. 2008; 37(1):9-22.

Würdig G. Levures produisant du SO2. Bulletin de l'OIV. 1985; 58(652-653):582-589.

Xu Y, Zhao G, Pan H, Li J. Effects of inhibitory environmental factors on growth of Oenococcus oeni CCSYU2068 for malolactic fermentation of cider production. J Inst Brew. 2005; 111: 223-228.

$\mathrm{Xu}$ Y, Zhao GA, Wang LP. Controlled formation of volatile components in cider making using a combination of Saccharomyces cerevisiae and Hanseniaspora valbyensis yeast species. $J$ Ind Microbiol Biotech. 2006; 33(3):192-196.

Zardo DM, Alberti A, Dantas APC, Guyot S, Wosiacki G, Nogueira A. Efeito do processamento no teor de compostos fenólicos e na atividade antioxidante em fermentados de maçã. Semina: Ciênc Agrar. 2008; 29: 829-838. 